\title{
News\&Comment
}

\section{Video shows state collusion with violent Israeli settlers}

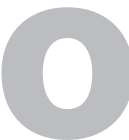

n 21st May 2012, The Guardian posted a shocking video that had been released by Israeli human rights group B'Tselem. The video shows Israeli settlers from the settlement of Yitzhar shooting at a group of Palestinian protesters in the West Bank village of Asira al-Qibliya while police and soldiers stand by. One of the settlers is seen crouching while aiming and then firing his pistol at the group of Palestinians. Two other settlers are seen firing assault rifles. Fathi Asayira, a 24-year-old Palestinian, is hit in the face and is seen in the video collapsed on the floor. He is taken to hospital with facial injuries following the shooting.

A shocking attack, but not surprising or unusual, as I know that the people of Asira have been experiencing violence and harassment from both the Yitzhar settlement and from the Israeli army since at least the year 2000. I know the village of Asira alQibliya from my time working with the Women's Centre for Legal Aid and Counselling (WCLAC) in Ramallah. We got to

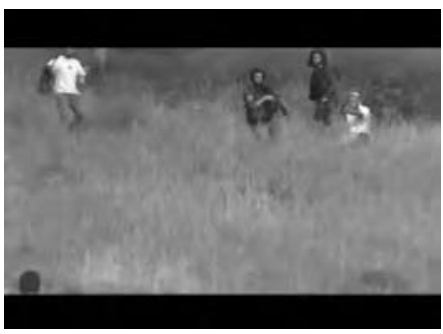

know some of the women in the village very well and visited regularly.

Colleagues and I from

WCLAC met Khadra for the first time in June 2009 in her home on the hillside just down from where the Jewish settlement of Yitzhar is located. She told us about the frequent attacks from Yitzhar settlers. She lives on the outskirts of the village and we could just see the settlement over the brow of the hill and also the Israeli military tent which is just 300 metres away from her house. She told us that she thought that there were 10 soldiers living in the tent but that they never did anything to stop the settlers from attacking the village.

Her family was one of the families that had been given video cameras by B'Tselem to record what happened when they were attacked by settlers.

A year later Khadra contacted us, devastated to tell us that her 16-year-old son Mohammed had been arrested by the Israeli army and that they didn't know where he had been taken. On 10th June 2010 the family had been woken up at 2 am by somebody shouting

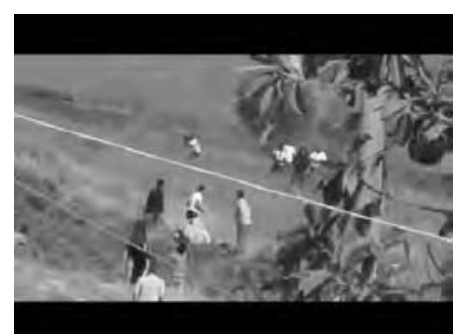

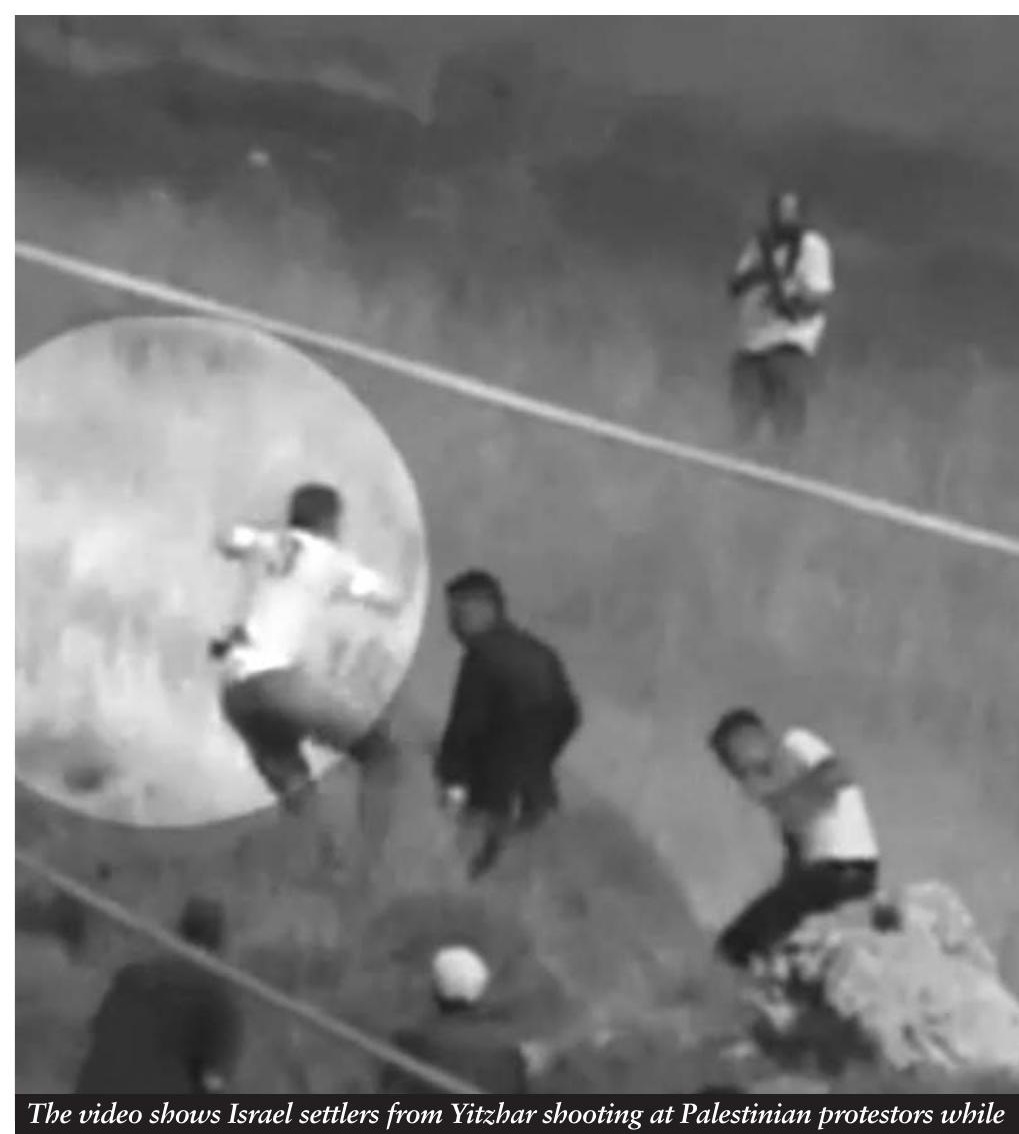

in Hebrew - 'army, army'. Mohammad's hands were tied with plastic ties, he was blindfolded and taken away on his own by Israeli soldiers. Khadra later found out that Mohammad and his friend, Fadi, were accused of starting a fire which had spread up the hillside from the village and threatened the settlement of Yizhar. Mohammed was held for 22days in Israeli interrogation and detention centres including six days in solitary confinement. He told his mother later how the interrogator had banged at the table violently to scare him, shouted at him and threatened to electrocute him if he didn't confess. He said he was terrified but still did not confess to something he did not do. Then on 1st July 2010, without prior notice, Israeli soldiers dropped the two boys off at a checkpoint far from their home at $8.30 \mathrm{pm}$ and told them to 'go home.'

Mohammed is one of just 700 Palestinian children who are arrested, interrogated, prosecuted and detained in the Israeli military court system each year. Children

\section{June}

8: The Government confirms that forced marriage will be outlawed in England and Wales. The Prime Minister said he was persuaded to act after listening to victims. However some rights groups expressed concern that it may discourage victims from coming forward.

\section{'An unfortunate logistics} planning problem' Molly Prince, boss of workfare firm Close Protection UK, on the job seekers her firm left to sleep under a bridge.
12: Ministers pledge to push

through legislation to give same-sex couples the right to marry. However, the move faced opposition from Tory backbenchers and the Church of England. The Home Office has had over 100,000 responses to its consultation.

\section{'I recall the drink, I don't recall the dinner' 'I can't remember' 'I don't recall' 'I don't think so'}

Prime Minister David Cameron in another display of selective memory during the Leveson inquiry. 
